\title{
Laboratory tests in uveitis
}

New developments in the analysis of local antibody
production

\author{
A. KIJLSTRA, ${ }^{1,2}$ G.J. VAN DEN HORN,${ }^{2}$ L. LUYENDIJK, ${ }^{1}$ \\ G.S. BAARSMA, ${ }^{3}$ C.M.C. SCHWEITZER, ${ }^{4}$ M.J.M. ZAAL,${ }^{5}$ \\ Z. TIMMERMAN,${ }^{6}$ M. BEINTEMA, ${ }^{7}$ \& A. ROTHOVA ${ }^{1,2}$ \\ ${ }^{1}$ The Netherlands Ophthalmic Research Institute; ${ }^{2}$ Dept. Ophthalmology, University of \\ Amsterdam; ${ }^{3}$ Dept. Ophthalmology, University of Rotterdam; ${ }^{4}$ Dept. Ophthalmology, \\ University of Leiden; ${ }^{5}$ Dept. Ophthalmology, Free University of Amsterdam; ${ }^{6}$ Dept. \\ Ophthalmology, University of Groningen; ${ }^{7}$ Dept. Ophthalmology, University of Maastricht
}

Accepted 18 July 1990

Key words: Aqueous humor, toxoplasma, cytomegalovirus, varicella zoster virus, herpes simplex virus, uveitis, diagnostic test

\begin{abstract}
Analysis of local intraocular antibody production is a valuable tool with which to confirm a suspected clinical diagnosis in uveitis. We have analysed paired serum and aqueous samples for the presence of specific antibodies against toxoplasma, cytomegalovirus, herpes simplex virus and varicella zoster virus. Of the patients retrospectively diagnosed as having toxoplasma chorioretinitis $75 \%$ had a positive antibody coefficient indicating specific antibody production in the eye. Local antibody production in the eye directed against CMV confirmed the suspected diagnosis of CMV retinitis in $50 \%$ of the AIDS patients investigated: So far we have not been able to demonstrate local antibody production against herpes simplex virus (26 samples tested). Two of three patients with acute retinal necrosis had a positive antibody coefficient against varicella zoster virus. Both of these patients had an even higher titer in the aqueous than in serum. Since the choice of therapy, in infectious uveitis, depends on the causative organisms, it is very important to confirm a suspected clinical diagnosis by means of aqueous humor analysis.
\end{abstract}

\section{Introduction}

Uveitis is an inflammation of the uveal tract which can be caused by either infectious or non-infectious mechanisms. It encompasses a great number of conditions, of which some are confined to the eye; others may be symptoms of systemic diseases such as ankylosing spondylitis, Behçet's disease, sarcoidosis, diabetes mellitus, juvenile rheumatoid arthritis or multiple sclerosis. Uveitis may also be caused by bacterial (tuberculosis, syphilis, 
borreliosis, leprosy), viral (cytomegalo-virus, herpes simplex), fungal (candida), protozoal (toxoplasmosis) or helminthic (onchocerca) infections.

In view of the fact that uveitis can be caused by so many different mechanisms it is extremely difficult to decide which laboratory tests should be performed. Since severe uveitis may lead to irreversible visual loss the practitioner is tempted to obtain as much information as possible. Nonselective requests for tests, however, may be quite costly, and recent experience [1] has shown that only a limited number of tests are really useful. Examination of various parameters in a peripheral blood sample often gives little information about an isolated process going on in the eye. More insight in the disease process can be obtained by analysis of tissue biopsies or fluid samples from the inflamed eye.

The availability of commercial tests for the detection of circulating antibodies against various bacterial and viral agents has revived the interest in anterior chamber paracentesis. The demonstration of local antibody production in the eye may be of help in confirming a clinical suspicion. In this report details of the laboratory techniques used and the interpretation of results will be discussed.

\section{Materials and methods}

Samples of aqueous humor (25-200 $\mu \mathrm{l})$ and venous blood $(10 \mathrm{ml})$ were taken in the Outpatient Departments of the various participating Ophthalmology Departments. Various techniques may be used to collect aqueous humor. At the Department of Ophthalmology of the University of Amsterdam the following procedure is followed. The patient is asked to lie down in an operating chair and, after local anaesthesia with drops, the anterior chamber is punctured. This is done with a disposable tuberculin syringe fitted with a $30 \mathrm{~g}$ needle. The plunger is removed before the puncture and the syringe fills spontaneously with aqueous. The advantage of this method is that it eliminates the need to draw back the plunger during paracentesis. Following paracentesis patients are treated with an antibiotic ointment. To prevent evaporation and leakage, the syringe is sealed at both ends during transportation.

In the laboratory the aqueous humor was removed from the syringe and as much fluid as possible collected using a $5 \mu$ l glass capillary. After clotting, the blood sample was centrifuged and the serum collected. Serum and aqueous were analysed immediately or stored at $-20^{\circ} \mathrm{C}$.

Total immunoglobulin $\mathrm{G}$ levels were determined in aqueous and serum using radial immunodiffusion. Aqueous was tested undiluted or in a $1 / 2$ 
dilution whereas the paired serum sample was tested in a $1 / 200$ dilution. Various dilutions of a normal human serum known to contain $10 \mathrm{mg} / \mathrm{ml}$ were used as a standard. Sample size for these determinations was $5 \mu 1$. The assay is normally performed in duplicate but when only very small amounts of aqueous were available a single assay was done. Toxoplasma antibodies were determined using an immunofluorescence test with glass-coated formalin-fixed toxoplasma organisms as described earlier [2]. Determination of antibodies against cytomegalovirus, herpes simplex virus and varicella zoster virus was performed as described earlier [3], using a commercially available test kit (Gull laboratories). In this assay glass slides are coated with virus-infected cells and the presence of viral antibodies in aqueous or serum is tested with an immunofluorescence assay. Serial two-fold dilutions are tested and the antibody titer was defined as the highest dilution still showing a positive result. Sample volume for each test is $10 \mu \mathrm{l}$. The amount of specific antibody in the eye, relative to the total amount of $\mathrm{IgG}$ in the eye, is calculated and divided by that found in serum. An antibody coefficient above 1.0 is theoretically suggestive of local production of specific antibody, but in view of the variation in the final test results a coefficient above 3 is arbitrarily considered significant.

\section{Results}

Most of our experience with anterior chamber paracentesis to collect aqueous humor for diagnostic purposes was obtained in cases with a suspect toxoplasma chorioretinititis. Of the patients who were finally diagnosed as having a toxoplasma chorioretinitis, $75 \%$ had a positive coefficient $(>3)$. In Table 1 the data on specific and total antibody are shown. Total IgG levels in the aqueous of these patients range between $18 \mu \mathrm{g} / \mathrm{ml}$ to $5000 \mu \mathrm{g} / \mathrm{ml}$. In most cases IgG levels do not exceed a value of $100 \mu \mathrm{g} / \mathrm{ml}$.

A negative coefficient was found in 5 cases. In 3 of these cases no antibody was detectable in the aqueous. In 2 other cases we did detect specific antibody in the aqueous but could not rule out that this was due to leakage from the blood compartment.

Local antibody production in the eye directed against CMV confirmed the suspected diagnosis CMV retinitis in $50 \%$ of AIDS patients investigated. No local CMV antibody production could be established in other samples tested (Table 2). In Table 3 some examples are shown of the analysis of CMV antibodies in the aqueous humor obtained from AIDS patients with a suspected CMV retinitis. In comparison with the data shown in Table 1 it is evident that the serum IgG levels are markedly raised in these patients 
Table 1. Toxoplasma antibody synthesis in the eyes of patients with toxoplasma chorioretinitis. *

\begin{tabular}{lrrrlr}
\hline Patient & $\begin{array}{l}\text { Serum } \\
\text { titer }\end{array}$ & $\begin{array}{l}\text { Aqueous } \\
\text { titer }\end{array}$ & Serum IgG & Aqueous IgG & C \\
\hline 1 & 64 & 2 & 8.2 & 0.065 & 3.9 \\
2 & 64 & NEG & 11.3 & 0.018 & - \\
3 & 256 & 32 & 7.6 & 0.173 & 5.5 \\
4 & 512 & 16 & 10.2 & 0.05 & 6.4 \\
5 & 256 & 128 & 11.2 & 5.0 & 1.1 \\
6 & 1024 & 32 & 11.0 & 0.052 & 6.6 \\
7 & 256 & 16 & 8.2 & 0.058 & 8.8 \\
8 & 64 & 16 & 15.6 & 0.037 & 105 \\
9 & 256 & 32 & 12.6 & 0.141 & 11.2 \\
10 & 256 & 8 & 7.0 & 0.132 & 1.7 \\
11 & 256 & 16 & 16.1 & 0.088 & 7.4 \\
12 & 256 & 16 & 9.2 & 0.082 & 45.6 \\
13 & 64 & 16 & 14.8 & 0.081 & 61.5 \\
14 & 32 & 4 & 12.8 & 0.026 & 4.8 \\
15 & 64 & 8 & 18.6 & 0.488 & 3.6 \\
16 & 256 & 8 & 7.4 & 0.064 & 6.6 \\
17 & 64 & 1 & 9.8 & 0.023 & 6.4 \\
18 & 64 & 4 & 7.2 & 0.07 & - \\
19 & 32 & NEG & 12.5 & 0.072 & - \\
20 & 256 & NEG & 12.4 & 0.078 & 23 \\
21 & 32 & 4 & 7.9 & 0.043 & 35 \\
22 & 64 & 8 & 12.6 & 0.035 & 23 \\
23 & 128 & 32 & 8.4 & 0.058 & \\
24 & 512 & 64 & 11.8 & 0.065 & \\
\hline
\end{tabular}

* IgG values are given in $\mathrm{mg} / \mathrm{ml} ; \mathrm{C}=$ antibody coefficient.

Table 2. CMV antibody synthesis in the eyes of patients with suspected CMV retinitis.

\begin{tabular}{ll}
\hline Patient group & Positive CMV antbody coefficient \\
\hline Retinitis and AIDS & $8 / 16$ \\
Senile cataract & $0 / 5$ \\
Posterior uveitis & $0 / 8$ \\
Acute retinal necrosis & $0 / 1$ \\
\hline
\end{tabular}

and values as high as $36 \mathrm{mg} / \mathrm{ml}$ may be found. The IgG levels in the aqueous, however, are comparable to those seen in toxoplasma patients.

Testing for intraocular antibody production against herpes simplex virus has produced negative results in all samples $(\mathrm{n}=26)$ tested so far, including 3 patients with acute retinal necrosis.

Two of the three patients with acute retinal necrosis had a positive antibody coefficient against varicella zoster virus. Both of these patients had an even higher titer in the aqueous than in serum (Table 4). 
Table 3. CMV antibody synthesis in the eyes of patients with AIDS and retinitis.*

\begin{tabular}{lccllc}
\hline Patient & $\begin{array}{l}\text { Serum } \\
\text { titer }\end{array}$ & $\begin{array}{l}\text { Aqueous } \\
\text { titer }\end{array}$ & Serum IgG & Aqueous IgG & C \\
\hline 1 & 128 & 8 & 18.1 & $>1.0$ & $<1$ \\
2 & 5120 & 8 & 25.1 & 0.042 & 0.9 \\
3 & $<2$ & NEG & 17.6 & 0.1 & - \\
4 & 80 & 8 & 18.0 & 0.2 & 9.0 \\
5 & 16000 & 32 & 25.2 & 0.024 & $<2.1$ \\
6 & 100 & 2 & 24.2 & 0.028 & 17.3 \\
7 & 40 & NEG & 15.9 & 0.14 & - \\
8 & 20 & 4 & 25.3 & 0.05 & 101 \\
9 & 400 & 8 & 17.3 & 0.128 & 2.7 \\
10 & 400 & NEG & 15.7 & 0.07 & - \\
11 & 2000 & 128 & 15.4 & 0.06 & 16.4 \\
12 & 320 & 8 & 36.8 & 0.11 & 8.4 \\
13 & 200 & 2 & 22.7 & 0.01 & 6.5 \\
14 & 640 & 16 & 20.4 & 0.078 & - \\
15 & 32 & NEG & 15.5 & 0.024 & 4.6 \\
16 & 64 & 2 & 13.0 & 0.088 & \\
\hline
\end{tabular}

* IgG values are given in $\mathrm{mg} / \mathrm{ml} ; \mathrm{C}=$ antibody coefficient.

\section{Discussion}

Determination of specific antibody production in the eye is a valuable diagnostic aid in the work-up of uveitis patients. It represents an indirect proof of the role of a microorganism in the pathogenesis of the intraocular inflammation. Direct proof would involve the culture of the microorganism or the detection of its' antigens. The culture of aqueous samples in uveitis has not been very helpful so far. As far as we know, no attempts to detect the free antigens of a suspected microorganism or its complex with antibody have been published. In the serological procedures for diagnosing acquired toxoplasmosis it is now routine to measure toxoplasma antibody, toxoplasma antigen and toxoplasma-containing immune complex in serum samples of the patient [4]. The combination of test results gives an appropriate indication of the activity of the infection. As the combination of these tests

Table 4. VZV antibody synthesis in the eyes of patients with acute retinal necrosis.*

\begin{tabular}{lllccr}
\hline Patient & $\begin{array}{l}\text { Serum } \\
\text { titer }\end{array}$ & $\begin{array}{l}\text { Aqueous } \\
\text { titer }\end{array}$ & Serum IgG & Aqueous IgG & C \\
\hline 1 & 80 & $>128$ & 11.3 & 0.143 & $>126$ \\
2 & 20 & 32 & 8.1 & 0.69 & 18 \\
3 & 160 & 32 & 9.7 & $>1.0$ & $>2$ \\
\hline
\end{tabular}

* IgG values are given in $\mathrm{mg} / \mathrm{ml} ; \mathrm{C}=$ antibody coefficient. 
requires substantial amounts of aqueous this line of procedure has not yet been followed in ocular immunology laboratories. The use of these techniques may however decrease the number of false negative results obtained due to blood-aqueous barrier breakdown combined with high specific serum antibody levels.

Negative test results may also be due to analysis of aqueous samples during an episode of low inflammatory activity. Furthermore, a false negative result may be caused by possible capture of these antibodies in immune complexes. Since intraocular biopsies or antigen tests are not performed in uveitis patients, the distinction between false negative and true negative coefficients may be very difficult to make and repeated aqueous analysis may be required. Another point is, that it is not yet clear where the antibody synthesis occurs in infectious uveitis entities and how intraocular antibody reaches the aqueous humor. In this context it is of interest that we have recently found very high toxoplasma antibody titers in a vitreous sample from a suspected toxoplasma chorioretinitis patient, which exceeded the serum titer four-fold. Although this possibly represents an incidental case, it may point to local antibody concentration differences within the eye.

Determination of local antibody production is relevant for the initial diagnosis and the subsequent choice of therapeutic measures to be taken. We have also observed that it may be useful in monitoring the effect of therapy in a small number of cases [3].

It is of interest that this diagnostic approach is being used in several centres in Europe and Japan but is not generally performed in the United States. So far no complications have been reported after aqueous chamber paracentesis. This does not imply that this procedure should be performed on every uveitis case. In patients with the typical clinical picture of a focal necrotizing lesion characteristic of toxoplasma chorioretinitis, additional laboratory testing is not needed. In certain unknown uveitis entities aqueous humor analysis may identify the causal organisms and be helpful in the precise determination of the clinical picture. In future cases with similar typical clinical findings aqueous analysis will therefore not always be needed. A stepwise approach may also be considered; first testing the serum for antibodies. If this is negative it is unlikely that the patients will have the suspected uveitic disease. If positive, one may proceed and collect a paired sample of aqueous and serum.

False positive results have been reported by Dussaix et al. [5]. To eliminate these we routinely test local antibody production against at least two different agents. A high coefficient against different antigens at the same time may raise suspicions about the test results or the uveitic condition of the patient. We have however not yet encountered an aqueous sample with a 
positive coefficient for more than one infectious agent, using the present criteria.

It is likely that the number of different organisms (Candida, Borrelia etc.) against which local ocular antibody production can be detected will increase in the near future. Since the choice of therapy, especially in infectious uveitis entities, depends directly on the causative organism, it is of utmost importance to confirm a clinical suspicion with a tailored request for aqueous humor tests.

\section{References}

1. Kijlstra A, Linssen A, Ockhuizen Th, Baarsma GS, Dandrieu MR, Tjoa St, de Graauw J, Christiaans BJ, de Jong PTVM, Dekker-Saeys AJ, Feltkamp TEW. Diagnostic tests in uveitis. In: KM Saari (ed), Uveitis Update. Amsterdam: Elsevier 1984; 421-425.

2. Kijlstra A, Luyendijk L, Baarsma GS, Rothova A, Schweitzer CMC. Timmerman Z, de Vries $\mathbf{J}$, Breebaart AC. Aqueous humor analysis as a diagnostic tool in toxoplasma uveitis. Int Ophthalmol 1989; 13: 383-386.

3. Luyendijk L, van der Horn GJ, Visser OHE, Suttorp-Schulten MSA, van de Biesen PR, Rothova A, Kijlstra A. Detection of locally produced antibodies to herpes viruses in the aqueous of patients with acquired immune deficiency syndrome (AIDS) or acute retinal necrosis syndrome (ARN). Curr Eye Res 1990; 9S: 7-11.

4. van Knapen F, Panggabean SO, van Leusden J. Demonstration of toxoplasma antigen containing complexes in active toxoplasmosis. J Clin Microbiol 1985; 22: 645-650.

5. Dussaix E, Cerqueti PM, Pontet F, Bloch-Michel E. New approaches to the detection of locally produced antiviral antibodies in the aqueous of patients with endogenous uveitis. Ophthalmologica 1987; 194: 145-149.

Address for correspondence: A. Kijlstra, MD, Department of Ophthalmo-Immunology, The Netherlands Ophthalmic Research Institute, P.O. Box 12141, 1100 AC Amsterdam ZO, The Netherlands. 